症例

胃癌切除後の多発大腸ポリープを呈した転移性大腸癌の 1 例

福山市市民病院外科

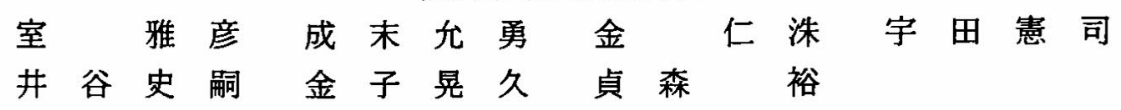

症例は67歳女性. 1992年 4 月に胃印環細胞癌にて胃要全摘術を施行している. 1995年 12月, 健診にて便潜血を指摘され来院した. 大腸内視鏡検查を施行したところ大腸には 4 力所の IIa +IIc 病変を認め, 同部の生検の結果, すべてに粘膜, 粘膜下に印環細胞癌 を認め胃癌よりの転移と考えられた.これより結腸亜全摘術を施行した。開腹時腹膜播 種はなく，16番リンパ節の腫大を認めた。胃癌切除後の多発大腸ポリープを呈した転移 性大腸癌は稀な症例である。

索引用語：多発大腸ポリープ, 胃癌, 転移性大腸癌

はじめに

転移性大腸癌は比較的稀で, なかでも切除可能な症 例は極めて少ない. 今回われわれは胃癌切除後に大腸 に多発性ポリープ様転移を認めた希有な1例を経験し たので報告する.

$$
\text { 症例 }
$$

患者：67歳，女性.

主訴：便潜血陽性.

家族歴：特記すべきことなし.

既往歴：1992年 4 月24日, 当科にて胃癌手術を施行. 胃下部幽門を中心に全周性に潰瘍浸潤型胃癌を認め胃 垔全摘を行った(図 1)，胃癌取扱い規約に基づく総合 所見は $\mathrm{t} 3$ （se）n3P0HOM0, Stage IVa, 根治度 B, 組織型は signet ring cell carcinoma, INF $\gamma$, se, ly3, v0，n3（3，4，6，7，8，14番に転移を認めた） であった.術後経過良好で, 外来にて経過観察中であっ た.

現病歴：1995年12月，検診で便潜血が陽性となり同 時に腫瘍マーカーCEA が $8.8 \mathrm{ng} / \mathrm{ml}$ と上昇したため, 自覚症状はなかったが精査を目的に1996年 1 月16日入 院した.

入院時現症：脈拍60回/分, 整, 血圧120/80 mmHg, 腹部に腫㿎など触知しなかった。

入院時検查所見 : 未梢血では $\mathrm{Hb} 10.3 \mathrm{~g} / \mathrm{dl}$ と軽度 の資血を認め, 生化学検査, 尿検査では特に異常を認

1998年 2 月25日受付 1998年6月11日採用
めず, 便潜血は陽性で, 腫瘍マーカーCEA が $8.8 \mathrm{ng} / \mathrm{ml}$ と上昇していた。

残胃内視鏡所見：慢性胃炎の他には著変を認めな かった.

注腸所見：S 状結腸と横行結腸にポリープ様隆起を 認めた（図 2 ).

大腸内視鏡所見 : S 状結腸, 下行結腸, 横行結腸, 上 行結腸にIIa +IIc 樣のポリープをそれぞれーカ所ず つ認めた(図 3a，b，c，d)．各部の生検の結果，すべ てが Group V (signet ring cell carcinoma) であっ た.

以上の結果より,胃癌から転移した大腸癌と診断し,

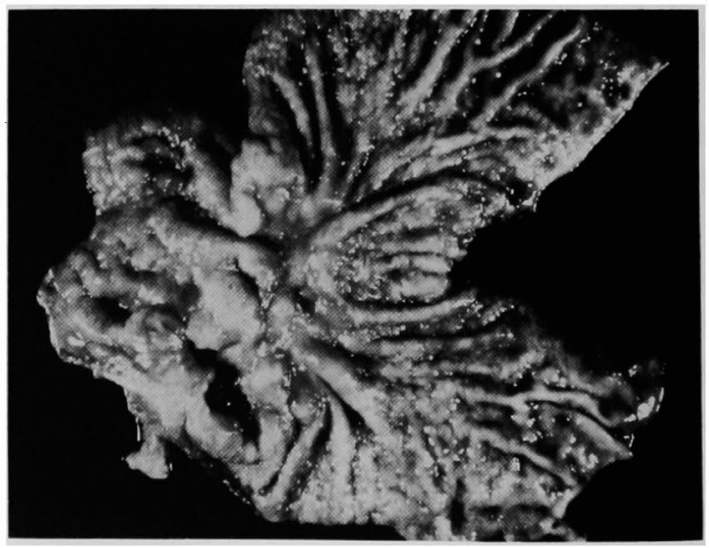

図 1 原発胃癌切除標本：胃下部幽門を中心とした全 周性謴漡浸潤型胃癌. 


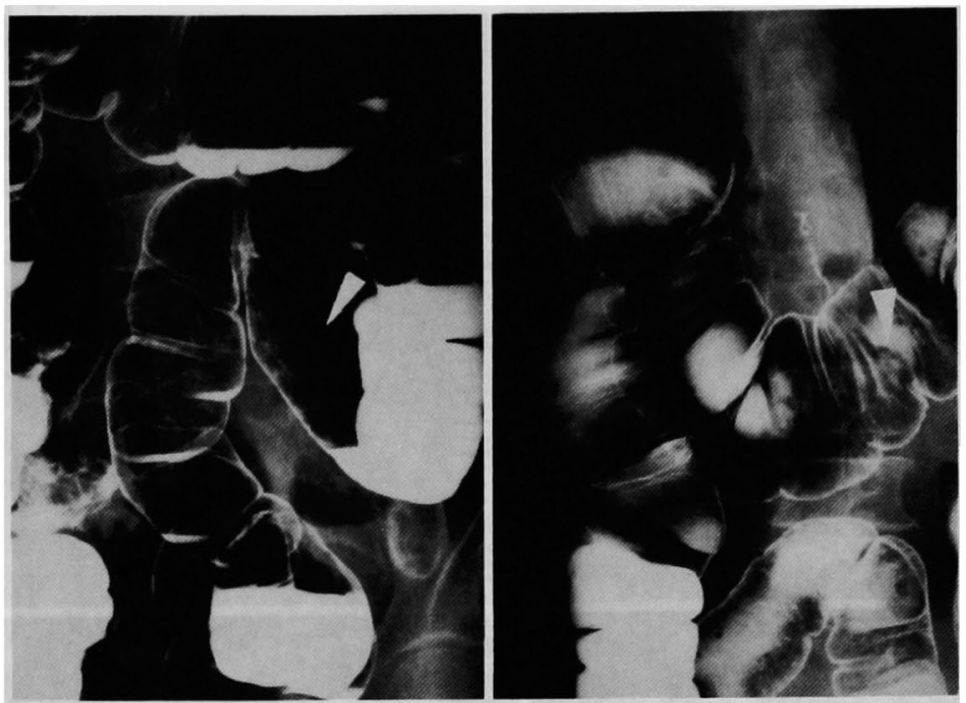

図 2 注腸所見：S 状結腸と横行結腸にポリープ様隆起を認めた（白矢印）.
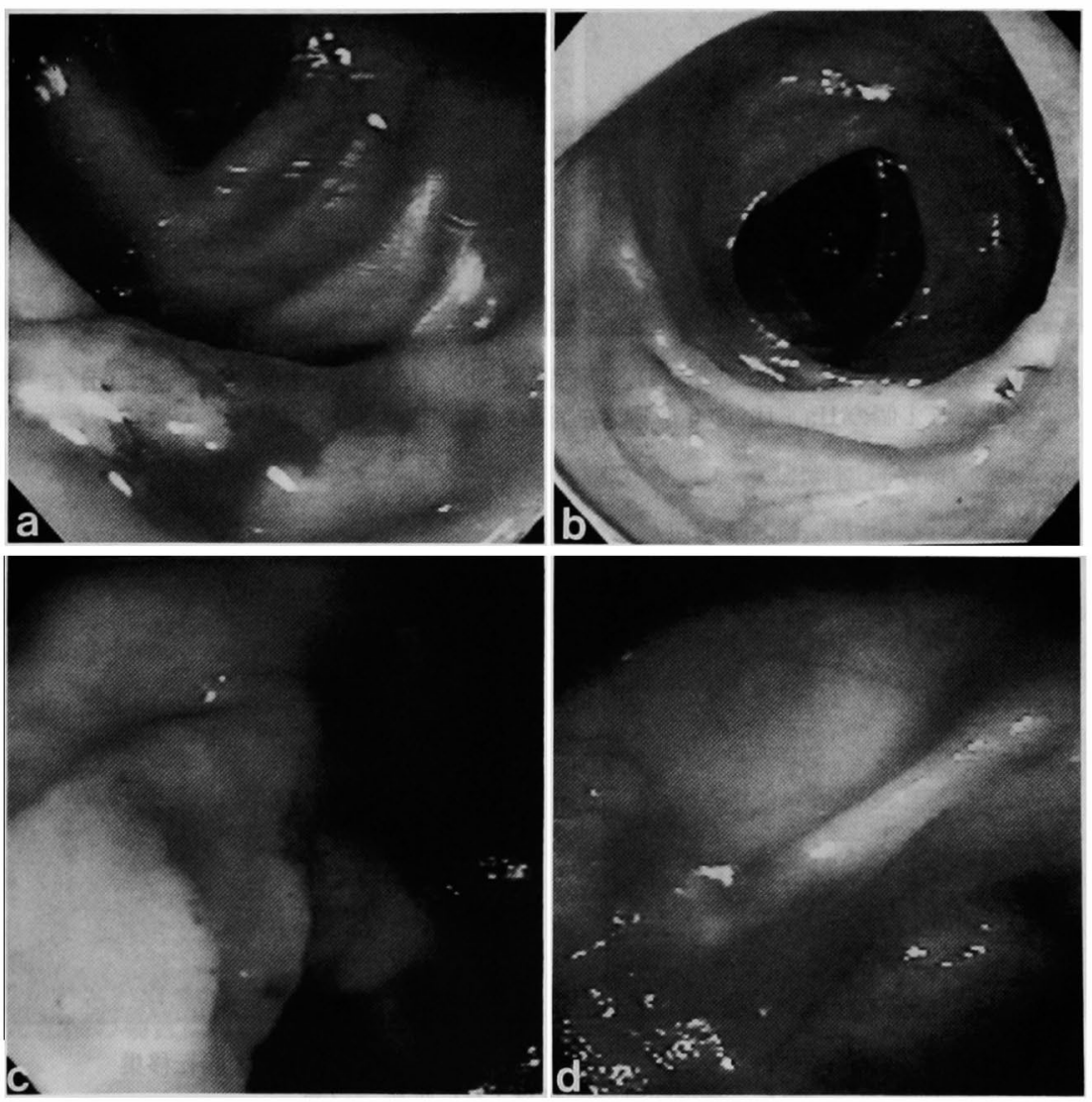

図 3 大腸内視鏡所見 : S 状結腸 (a), 下行結腸 (b), 横行結腸 (c), 上行結腸 (d) にそれそれ IIa+IIcのポリープを 1 カ所ずつ諰めた。 

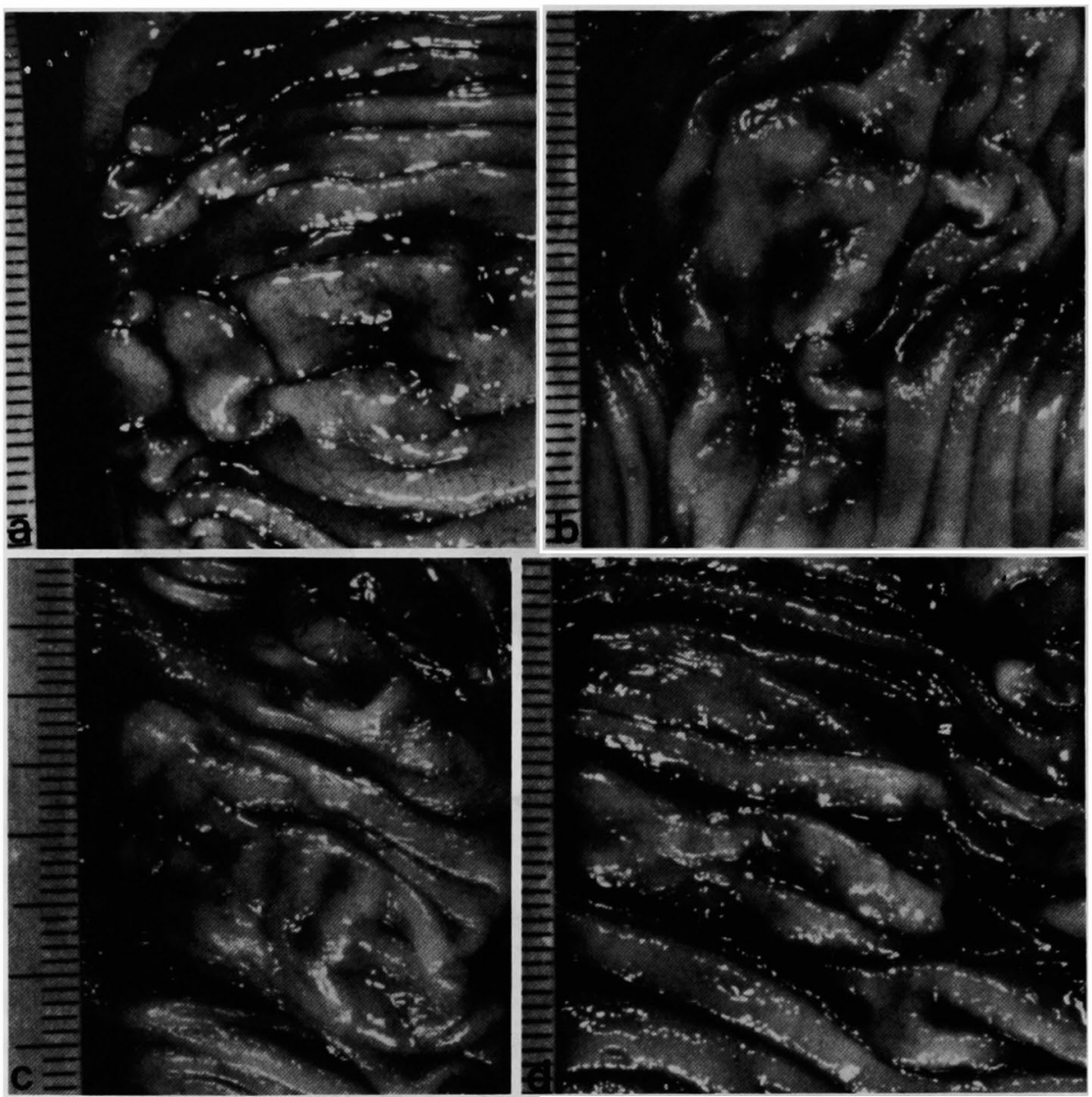

図 4 切除標本所見 : S 状結腸 (a), 下行結腸 (b), 横行結腸 (c), 上行結腸（d）に それぞれ 1 個の IIa+IIc の 0 型腫崵を認めた。

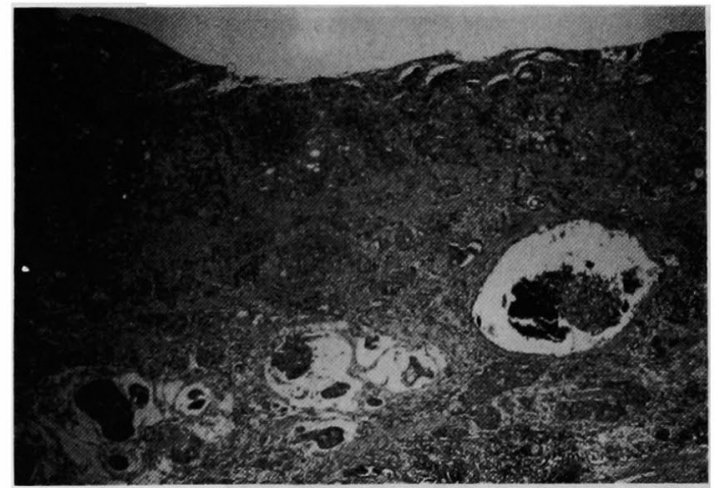

a. 原発胃癌

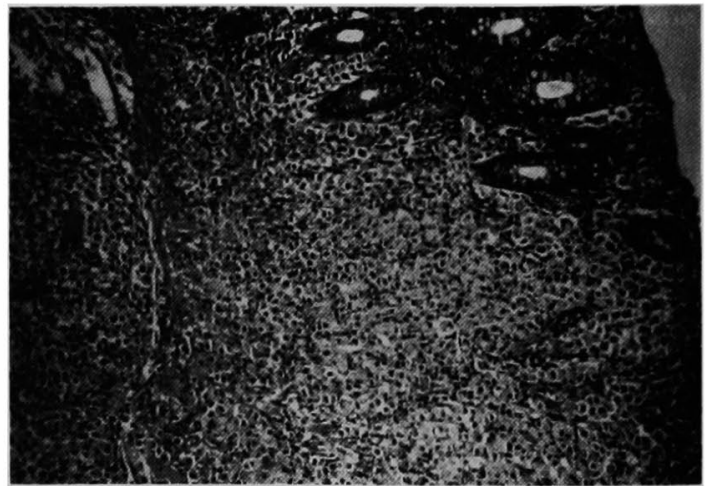

b. 大腸転移巣

図 5 病理組織学的所見 : HE 染色, $\times 400$ 
1月24日手術を施行した.

手術所見：下腹部正中切開にて開腹, 始め腹膜播種 による転移を疑っていたが，p0であった．腫場壁進達 度もすべて T1（M，SM）であったが，16番リンバ節 の腫大を認めた。結腸亜全摘術を施行し, 回腸一S 状結 腸を層々端々吻合した.リンパ郭清は第 1 群にとどめ た.

切除標本所見 : S 状結腸, 下行結腸, 横行結腸, 上行 結腸にそれぞれ 1 個の IIa+IIcの0 型腫掦を認めた (図 4a,b,c,d).

病理組織学的所見：腫瘍の壁深達度は S 状結腸 $(\mathrm{m})$, 下行結腸 $(\mathrm{sm})$, 横行結腸 $(\mathrm{sm})$, 上行結腸 $(\mathrm{m})$ でありすべてに signet ring cell carcinoma が認め られ(図 5)，胃癌から大腸粘膜面への転移と考えられ た.

術後経過は良好で，30日目に退院したが3カ月後に 16番リンパ節の腫大が原因と考えられる腎不全をきた し，腎瘦をおいたが効果なく死亡した．剖検は家族の 同意が得られず施行していない。

\section{考 塞}

転移性大腸癌は比較的稀な疾患である．原発巣とし て胃, 卵巣, 子宮, 脺蔵, 乳腺, 肺, 腎臓, 前立腺な どが報告されている゙2)。なかでも自験例と同様に胃癌 の頻度が最も多い3). その占拠部位は横行結腸が最も 多く, 次いで S 状結腸, 直腸, 脾彎曲部, 下行結腸, 上行結腸, 盲腸の順で多い4). 胃癌原発巣の肉眼型は浸 潤型が多く，槳膜面に広く露出した症例が大部分で あった。組織型は印環細胞癌，低分化腺癌が多い4).転 移性大腸癌の肉眼形態はほとんど浸潤型で, 転移巣は 粘膜下腫激状で主として腸管壁外に発育することが多 いが, 自駼例では腹膜播種がなく, 粘膜, 粘膜下層に 限局してポリープ状に発育した稀な症例で，著者らが 文献検索した範囲では 2 例しか報告がない ${ }^{516)}$. 転移様 式は腹膜播種によるものが最も多いが，他に血行性， リンパ行性によるものもある，自験例では腹膜播種が なく, 原発巣の病理組織型検索で v0, ly3であったこと よりリンパ行性転移が最も考えられた。

転移性大腸癌の診断方法として，宮川7〕胃癌の大 腸転移の診断能を注腸と CT で比較検討し, 進行した 転移の場合には注腸と CT で診断能が同等であること が多く, 限局した転移の場合には, 注腸が CTよりも
診断能に優れることが多いと報告している。 注腸所見の特徵は収束, 圧排, びまんの 3 型で, な かでも収束型が最も特徵的な X 線像とされている8 内視鏡所見では, 内腔の狭小化, 伸展不良, 色調は退 色し浮腫状で, 結節状隆起や濽場形成も認められるが, 原発性大腸癌との鑑別には病理診断が最も重要で, 原 発巣と転移巣の組織像が一致することである. 自験例 では，これらの特徵的検查所見が当てはまらず，病理 診断にて初めて転移性大腸癌と診断可能であった。本 例の反省から，低分化型進行胃癌術後には，大腸転移 も念頭において，定期的に注腸検査や内視鏡検查を行 い，手術可能な時期に転移巣を発見することが予後の 向上に寄与するものと考えられた.

\section{結語}

胃癌切除後の多発大腸ポリープを呈した転移性大腸 癌の 1 手術例を経験したので, 若干の文献的考察を加 え報告した。

本症例の要旨は第58回日本臨床外科医学会総会（1996年 10月，京都）にて報告した。

\section{文 献}

1) Meyers MA, McSweeney J: Secondary neoplasms of the bowel. Radiology $105: 1-11,1972$

2) Haubrich WS: Adenocarcinoma of the breast metastatic to the rectum. Gastrointest Endosc $31: 403-404,1985$

3）三輪晃一，山口明夫，喜多一郎 他：胃癌の結腸再 発。消外 $6: 751-756,1983$

4）太田博俊, 畦倉 毫, 関 誠他：転移性大腸癌の 臨床病理，胃と腸 23:633-643, 1988

5) Ogiwara H, Konno H, Kitayama $\mathrm{Y}$, et al: Metastases from gastric adenocarcinoma presenting as multiple colonic polyps: Report of a case. Surgery Today $24: 473-475,1994$

6) Metayer $P$, Antonietti $M$, Oumrani $M$, et al: Metastases of a gastric adenocarcinoma presenting as colonic polyposis: Report of a case. Dis Colon Rectum 34 : 622-623, 1991

7）宮川国久：胃癌の大腸転移の画像診断.千葉医学 $70: 245-250,1994$

8）石川 勉, 縄野 繁, 水口安則他：転移性大腸癌の 形態診断一X 線像の解析を中心に一. 胃と腸 23 ： 617-630, 1988 
A CASE OF METASTASES FROM GASTRIC ADENOCARCINOMA PRESENTING AS MULTIPLE COLONIC POLYPS

\author{
Masahiko MURO, Mitsuo NARUSUE, Hitoshi KIN, Kenji UDA, Hitoshi IDANI, \\ Akihisa KANEKO and Hiroshi SADAMORI \\ Department of Surgery, Fukuyama Municipal Hospital
}

A 67-year-old woman was seen at the hospital because her stool was positive for occult blood at a medical checkup in December, 1995. Previous history disclosed that she underwent a subtotal gastrectomy for signet ring cell carcinoma of the stomach in April, 1992. After admission to the hospital, a total colonoscopy detected four Ila + IIc type polyps. The colonic polyps were diagnosed as metastases to mucosal and submucosal lesions from the original gastric carcinoma.

A subtotal colectomy was performed. During operation no carcinomatous peritonitis was present but only paraaortic lymph node metastasis was seen.

It is rare that colonic metastases from gastric carcinoma presented as multiple colonic polyps like in this case. 